\title{
Influence of a Sterile Dark Mycelial Fungus on Take-all of Wheat
}

\author{
Yasusaburo NARITA* and Takahito SuzUI**
}

\begin{abstract}
Take-all of wheat outbreaks habitually in continuous cropping fields and causes the loss of wheat crop. In Hokkaido, however, it has never occurred in the long-term continuous fields for more than 25 years. In the field of this area a 'sterile dark mycelium' was frequently isolated from roots of wheat. An experiment was conducted to investigate the influence of this fungus on the incidence of take-all. The incorporation of this fungus in the soil infested with Gaeumannomyces graminis var. tritici reduced the infection of takeall fungus to wheat in pot experiments. The fungus forms no spores and its identification has not yet been accomplished.
\end{abstract}

(Received January 23, 1989)

Key words: wheat, Gaeumannomyces graminis var. tritici, sterile dark mycelial fungus, biological control.

\section{INTRODUCTION}

It has been demonstrated that infection of cereal roots by the wheat take-all fungus Gaeumannomyces graminis (Sacc.) Arx et Olivier var. tritici Walker (Ggt) was reduced by prior colonization of non or weakly pathogenic root-infecting fungi in pot and field experiments. Such fungi include a sterile, black mycelial fungus ${ }^{10)}$, Phialophora framinicola Deacon ${ }^{1,2,4,6,9)}$, a lobed hyphodiate Phialophora sp. synonymous with $P$. radicicola var. radicicola sensu Deacon ${ }^{3,4,7,8)}$ and G. graminis var. graminis ${ }^{11,12)}$.

A provisional name Sterile Dark used in this study were isolated from the root of wheat grown at continuous wheat cropping field in Hokkaido; this is the first record of this fungus in Japan. The funfus was isolated from root segments of apparently healthy wheat plants. Classification of this fungus is yet impossible due to the lack of sporulation.

Colonization of this fungus has been found to be very extensive on the wheat roots, even on that of relatively young stage of growth. We hypothesized that this fungus could successively compete with Ggt on the wheat root and reduce the take-all incidence. Thus an experiment was designed to investigate it.

\section{MATERIALS AND METHODS}

Ggt was isolated from root lesions of wheat infected with take-all and Sterile Dark were isolated (Figs. 1 and 2) from healthy roots of wheat grown in the field where there had been con-

* Hokkaido Nuclear Environmental Observation Center, Kyowa-cho, Iwanai-gun, Hokkaido 045-01, Japan 北海道原子力環境センター

** National Institute of Agro-Environmental Sciences, Tsukuba, Ibaraki 305, Japan 研究所 


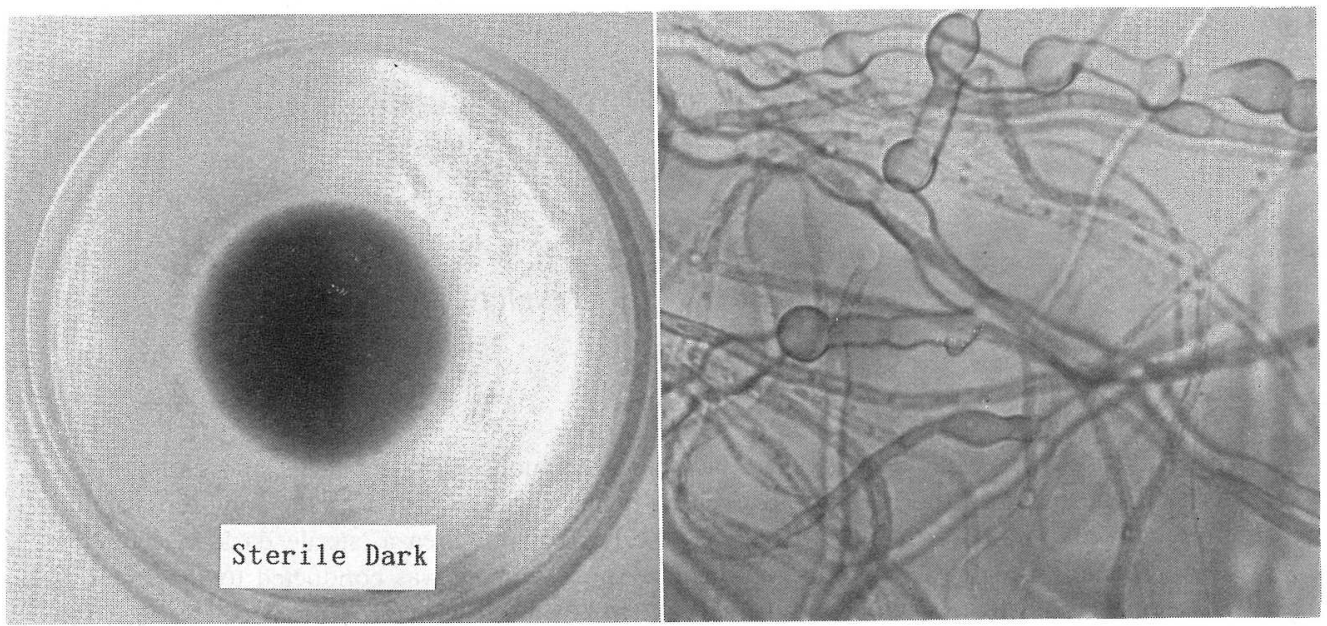

Fig. 1. The isolates of Sterile Dark from wheat root, cultured on potato dextrose agar at $25^{\circ} \mathrm{C}$ for 17 days. The isolates of Sterile Dark were isolated from healthy roots of wheat grown in the field where there had been continuous cropping over 25 years. Left: appearance of colony, right: the submerged mycelium with chlamydospore-like structure.

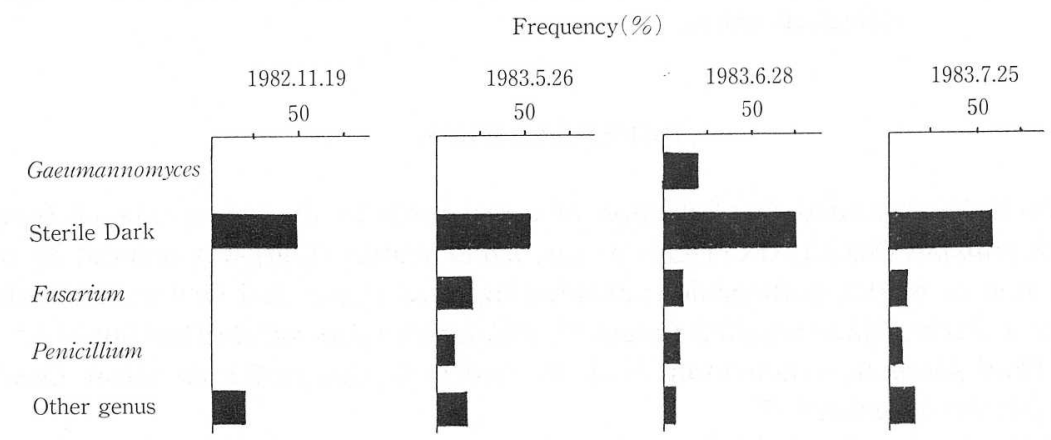

Fig. 2. Isolation frequencies of fungi from wheat roots ( $\%$ of 40 segments). Isolation of the fungi was carried out using the method by Harley and Waid.

tinuous cropping over 25 years. Isolation of the fungi was carried out using the method by Harley and Waid ${ }^{5}$.

Fungus inocula were prepared by inoculating with mycelial discs of the fungus to sterile oat grains in $300-\mathrm{ml}$ Erlenmeyer flasks. These were incubated at $25^{\circ} \mathrm{C}$ and shaken at approximately weekly intervals for 14 days. The fully colonized oat grains were then air-dried, ground in Waring blender and stored at $5^{\circ} \mathrm{C}$ until use. Sandy loam soil taken from a field at the National Institute of Agro-Environmental Sciences was used in the experiment. The soil was passed through a $2-\mathrm{mm}$ sieve and sterilized at $100^{\circ} \mathrm{C}$ in an autoclave for $1 \mathrm{hr}$ before use.

Sterile Dark and Ggt inocula were mixed into the soil at $1.5 \%$ and $0.5 \%(\mathrm{v} / \mathrm{v})$, respectively. Four treatments were prepared as follows: noninoculated control; inoculation of Ggt alone; inoculation of Sterile Dark alone; and mixed inoculation of Ggt and Sterile Dark. The soil mixtures were used to fill $20 \times 20 \mathrm{~cm}$ china pots with three replicates for each treatment.

The pots were then sown with thirty seeds of winter wheat at a depth of $1 \mathrm{~cm}$, and watered. The plants were removed from the pots 80 days after sowing and the above-ground parts were dried at $65^{\circ} \mathrm{C}$. Their dry weights were recorded. 
The segment samples taken from all the plants were washed twenty times in freshly changed water. The samples were then surface-sterilized for $60 \mathrm{sec}$ in 20 -fold $\mathrm{NaOCl}$, and finally plated onto Czapek-Dox agar medium. The percentage of root segments colonized by either Ggt or Sterile Dark, or both, was recorded after 10 -day incubation at $25^{\circ} \mathrm{C}$. Sterile Dark was distinguished from Ggt by characteristics of the colonies on the medium. Some of the roots were also examined under a dissecting microscope at a magnification of $\times 300$ for the occurrence of Sterile Dark runner mycelia on or in the wheat roots.

\section{RESULTS AND DISCUSSION}

Morphological and cultural characteristics of Sterile Dark isolated from wheat roots are as follows: Colonies on potato dextrose agar (PDA); white to gray, later becoming dark gray. Vegetative hyphae smooth walled, septate, pigmented occasionally having chlamydospore-like structure, colonies grow slowly at $25^{\circ} \mathrm{C}$, uniform in surface feature with aerial mycelium, min. temp. $7^{\circ} \mathrm{C}$, opt. $23^{\circ} \mathrm{C}$, max. $30^{\circ} \mathrm{C}$ for development. No spores formed on the artificial media or the organic materials (Fig. 1).

As the results of the inoculation tests, the inoculation of Ggt caused take-all of wheat conspicuously. A mixed inoculation of the Sterile Dark and Ggt clearly suppressed the incidence of take-all as compared with the inoculation of Ggt alone (Fig. 3).

Effect of Sterile Dark on dry weights of the above ground parts of wheat grown in the soil infested with Ggt was given in Table 1. The result showed that the dry weights of wheat which had been grown in the soil amended with Sterile Dark alone and with Ggt plus Sterile Dark were significantly greater than that in the Ggt treatment.

Ggt and Sterile Dark were recovered at a higher frequency from the roots of wheat inoc-

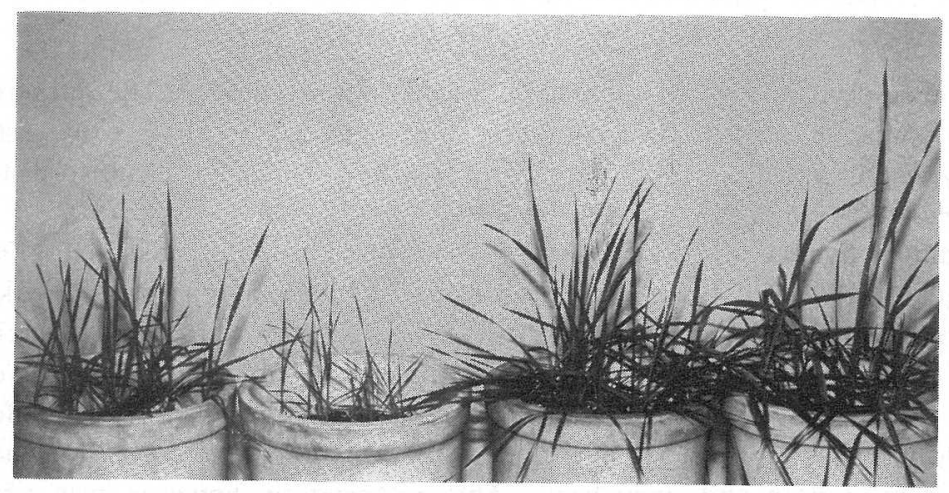

Fig. 3. Effect of Sterile Dark on the growth of wheat in the infested soil with take-all fungus, Gaeumannomyces graminis var. tritici (Ggt). From left to right; noninoculated control, Ggt alone, Sterile Dark alone, Ggt + Sterile Dark. The measured dry weights are given in Table 1.

Table 1. Effect of Sterile Dark fungus on dry weights of the above-ground parts of wheat grown in the soil containing take-all fungus, Gaeumannomyces graminis var. tritici (Ggt)

\begin{tabular}{lc}
\hline \hline Treatment & Mean dry weight $\left.(\mathrm{g})^{\mathrm{a}}\right)$ \\
\hline Non-inoculation & 1.53 \\
Ggt & 0.50 \\
Sterile Dark & 2.03 \\
Ggt + Sterile Dark & 2.02 \\
\hline
\end{tabular}

a) Mean values from three replicates. 
Table 2. Reisolation frequencies of Gaeumannomyces graminis var. tritici (Ggt) and Sterile Dark from the roots of the wheat plants

\begin{tabular}{lcc}
\hline \hline Treatment & Ggt $(\%)^{a)}$ & Sterile Dark (\%)a $)^{\text {a }}$ \\
\hline Non-inoculation & 0 & 0 \\
Ggt & 42.5 & 0 \\
Sterile Dark & 0 & 77.5 \\
Ggt + Sterile Dark & 27.5 & 42.5 \\
\hline
\end{tabular}

a) The percentage of the plated root segments colonized by either Ggt or Sterile Dark, or both, were recorded 10 days after inoculation at $25^{\circ} \mathrm{C}$.

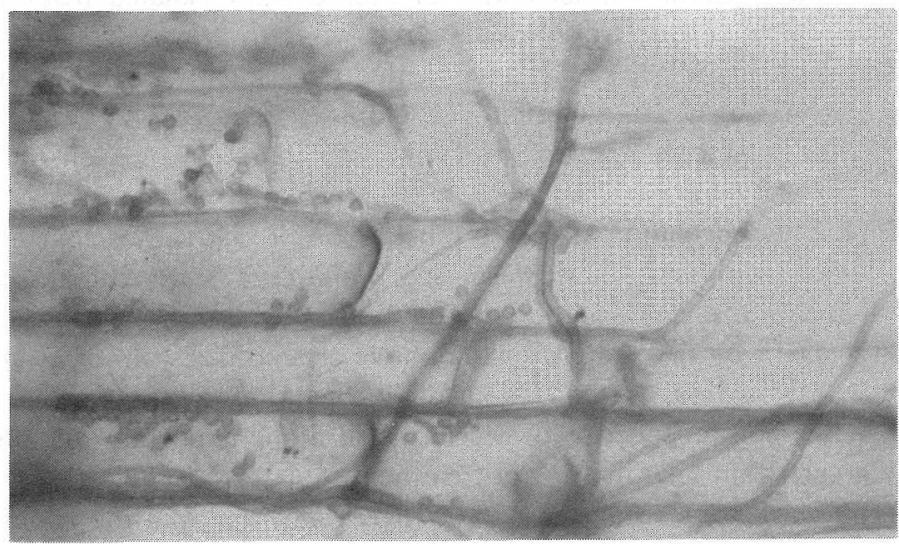

Fig. 4. Typical runner mycelium of Sterile Dark in wheat roots.

ulated with the respective fungi 10 days after inoculation (Table 2). The dark runner hyphae of Sterile Dark were observed independently on the presence or absence of a stellar necrosis on roots. Hyphae of Sterile Dark and Ggt in the wheat roots were difficult to distinguish under the microscopic observations.

Typical runner hyphae of Sterile Dark in wheat roots are illustrated in Fig. 4. It appears that this fungus is similar to a sterile, black mycelial fungus referenced by Speakman et al. ${ }^{10)}$, which is a mold fungus isolated from corn roots. Sterile Dark, similar to a sterile, black mycelial fungus, formed no spores. Inoculation of a sterile, black mycelial fungus on wheat and barley in the infested soil with Ggt conducted almost the same suppression effect ${ }^{10}$. Sterile Dark was colonized on the root systems of a wide range of plant species, including soybean, adzuki bean, corn, potato and sugar-beet. This colonization, however, was restricted to the epidermis and outer cortical cell layers with external runner hyphae and poor infection hyphae of this fungus (Narita, unpublished data).

A test for applicability of suppressible effect of Sterile Dark to natural field conditions are currently in progress and will be reported in the future.

\section{Literature cited}

1. Balis, C. (1970). A comparative study of Phialophora radicicola, an avirulent fungal root parasite of grasses and cereals. Ann. appl. Biol. 66: 59-73.

2. Deacon, J.W. (1973). Control of the take-all fungus by grass leys in intensive cereal cropping. PI. Path. 22: 88-94.

3. Deacon, J.W. (1974). Further studies on Phialophora radicicola and Gaeumannomyces graminis on roots and stem bases of grasses and cereals. Trans. Br. mycol. Soc. 63: 307-327. 
4. Deacon, J.W. (1976). Biological control of the take-all fungus, Gaeumannomyces graminis by Phialophora radicicola and similar fungi. Soil Biol. Biochem. 8: 275-283.

5. Harley, J.L. and Waid, J.S. (1955). A method of studying active mycelia on lining roots and other surfaces in the soil. Trans. Br. mycol. Soc. 38: 104-118.

6. Scott, P.R. (1970). Phialophora radicicola, an avirulent parasite of wheat and grass roots. Trans. Br. mycol. Soc. 55: 163-167.

7. Speakman, J.B. (1977). Interactions between Gaeumannomyces graminis and Phialophora radicicola in relation to take-all disease of wheat. Ph.D. Thesis, University of East Anglia, Norwich.

8. Speakman, J.B. and Lewis, B.G. (1978). Limitation of Gaeumannomyces graminis by wheat root responses to Phialophora radicicola. New Phytol. 80: 373--380.

9. Speakman, J.B., Cowan, M.C. and Lewis, B.G. (1978). Control of the take-all disease of wheat by grass and legume species. P1. Path. 27: 58-65.

10. Speakman, J.B. and Kruger, W. (1984). Control of Gaeumannomyces graminis var. tritici by a sterile, black mycelial fungus. J. PI. Dis. Protec. 91: 391-395.

11. Wong, P.T.W. (1975). Cross-protection against the wheat and oat take-all fungi by Gaeumannomyces graminis var. graminis. Soil Biol. Biochem. 7: 189-194.

12. Wong, P.T.W. and Southwell, R.J. (1980). Field control of take-all of wheat by avirulent fungi. Ann. appl. Biol. 94: 41-49.

\section{和 文 摘 要}

\section{成田保三郎・鈴井孝仁：コムギ立枯病に対する糸状菌「Sterile Dark」の影響}

一般に秋播コムギを連作するとコムギ立枯病が発生し，大きな減収を招くことになる。しかし，北海道で 25 年間連作していてもコムギ立枯病は発生せず，安定した収量を維持している畑があるので，その原因を 調査した結果，連作コムギの根から「Sterile Dark」と仮称した糸状菌が高頻度に分離された。そのため，本 菌が連作による立枯病の発生を阻止している可能性があると考光, 本菌とコムギ立枯病菌の両方を土壤へ接 種したところ，コムギ立枯病の発生が軽減された。な和本菌は目下のところ胞子を作らないため, 同定され ていない。 